\title{
The Influence Of Organizational Culture On Work Motivation, Work Satisfaction And Innovative Behavior In Improving Employee Performance
}

\author{
Efni Efridah \\ \{efni101722@gmail.com\}
}

\author{
Student of the Education Management Doctoral Program at Medan State University
}

\begin{abstract}
The formation of an organization is due to the goals to be achieved in the future, which are influenced by the behavior and attitudes of the people who are part of the organization who work together in achieving its goals. The organization will not be able to achieve its stated goals without the support of members of the organization, both government and private organizations. There are several work environment factors in accordance with the conditions experienced by employees, especially in the Tebing Tinggi City Education Office, namely working conditions, policies and procedures, leadership styles, working group relations, benefits or incentives and adequate facilities. These factors become a phenomenon that occurs in an organization especially seen from the aspects of organizational culture so that it becomes an internal factor and external factors in improving employee performance. These internal factors and external factors can become obstacles or become supporters in achieving organizational goals through motivation, job satisfaction and innovative behavior in employee performance. The link between organizational culture and improving employee performance through motivation, job satisfaction and innovative behavior is expected by every organization, especially government organizations such as the Tebing Tinggi City Education Office.
\end{abstract}

Keywords : organizational culture, work motivation, job satisfaction, innovative behavior and performance

\section{Introduction}

Every organization needs potential human resources both leaders and employees in the pattern and supervision that is the determinant of the achievement of the goals and progress of the organization. Optimizing the progress of related organizations is also by creating a comfortable environment such as a harmonious relationship between leaders and employees as well as between employees and other employees. To deal with the demands of these changes, each organization must be able to carry out innovations that seek to form policies that are in line with environmental changes. One formulation of the policy is related to improving human resource capacity. Handoko (2014) explains that the most important resource of an organization is human resources, people who give their energy, talent, creativity and effort to the organization.

The achievement of organizational goals is also influenced by the organizational culture, which is related to the values, assumptions, and basic beliefs that are felt together and everyone as a member of the organization, so that if it takes place in a conducive manner it will cause a sense of comfort which then encourages concerned have a commitment to the organization. Yusniar (2016), defines organizational culture as values, symbols that are understood and obeyed together, which is owned by an organization so that members of the 
organization feel one family and create a condition that members of the organization feel different from other organizations.

The success of the organization in developing a good organizational culture is also the success of the performance of its employees. Organizational culture is the most important thing to create motivation, job satisfaction and innovative behavior of employees in improving their performance

The phenomenon that occurs in the Tebing Tinggi City Education Office, still shows that employees tend to want to be placed in a wet position (profitable) so that it can work optimally, but if it is placed that is not wet (unfavorable) then the employee does not work optimally. This has become an obstacle in improving the performance of employees in the Tebing Kota Education Office.

Regarding the phenomenon of employee placement, there must be procedures and policies that can regulate and support the improvement of employee performance so that it can be adjusted to the expertise and ability in placing positions within the Tebing Tinggi City Education Office. The success of achieving organizational goals depends not only on modern equipment, complete facilities and infrastructure but more dependent on the people who carry out the work.

Employee performance will be good if they have high expertise, and have high motivation to achieve organizational progress, namely the Tebing Tinggi City Education Office. Thus, each employee must have a commitment to all policies and activities in the Tebing Tinggi Education Office, because the commitment given by employees is also a supporting factor for organizational progress that can increase job satisfaction resulting in innovative behavior.

The level of job satisfaction can also affect employee behavior to make changes in work in achieving organizational goals. The impact of organizational culture can also have consequences for the innovative behavior of individuals both positive and negative. However, the expectations of each organization, especially the Tebing Tinggi Education Office, any changes that exist within the organization can be a positive change for employees to work in order to produce capabilities that can support organizational progress.

\section{Discussion}

An organization also has its own values, rules and policies for achieving goals. Kottler and Heskett (1998) stated that organizational culture is a strategic factor in explaining performance, both organizational performance and people's performance, therefore there are three types of organizational culture, namely strong or weak organizational culture, suitable and inappropriate organizational culture, and organizational culture can adjust (adaptive) and that cannot adjust. Organizational culture is the values, norms / rules that are used as role models in the organization in achieving goals. Wallace, et al (1999), explained that the development of organizational culture and job satisfaction can create a positive organizational climate as an absolute need to be able to encourage the creation of innovative behavior. Apart from the organization also from the individual itself is motivated to make innovations in the implementation of work. There are several characteristics of humans who behave innovatively, among others: 1) being open to innovation, 2) having a positive perception of the potential for innovation, 3) appreciating the creativity of one's innovation, 4) always ready to face social change, 5) broad-minded, 6 ) have a strong curiosity drive, 7) oriented to the present and the future from the past, 8) oriented and believe in planning, 9) more trust in the 
results of human calculations and human thought than destiny or disposition, 10) respecting complete human skills, 11) fully aware of the impact of the decisions he makes.

The importance of an organizational culture is a topic in management because in an organization there are a number of individuals who have different characteristics, but must have a shared commitment and become a working team in achieving goals. The emergence of organizational culture is influenced by various factors related to the existence of the organization. Nankervis, et al (1993), identified a number of factors that influence organizational culture including company history, current management style, size, structure, nature of service products, industrial relations activities and national culture. Prayudhayanti (2014), the organizational culture that develops in an organization cannot be separated from the dynamics of the internal and external elements of the organization.

The application of organizational culture is defined as a means to measure the suitability of organizational goals, strategies and the resulting impact. Without a valid and reliable measure of the critical aspects of organizational culture, the impact of organizational culture in improving performance cannot be seen or speculated. The suitability of this measurement is also related to the purpose of organizational formation. Tika (2006) argues that in the formation of organizational culture there are two important things that must be considered, namely the elements forming the organizational culture and the process of forming the organizational culture itself.

Characteristics of organizational culture are the foundation for an organization in carrying out work so as to produce optimization of productivity. Organizational culture must be able to put pressure on people involved in the organization to be able to act in a predetermined direction. Building an organizational culture that can support organizational change requires a tool, namely effective communication. With the existence of effective communication, the organization can communicate to each member the importance of change, so that it can accommodate all the aspirations and suggestions needed for the progress of the organization.

Encouragement in an organization means motivation. In general, motivation is interpreted as encouraging, activating, moving and channeling one's behavior, attitudes and behavior in achieving organizational goals. Robbins (2008), motivation is the desire to do something as a willingness to issue a high level of effort in achieving organizational goals that are conditioned by individual abilities. Masrukhin and Waridin (2006) suggested that motivation is a psychological factor that shows an individual's interest in work, satisfaction, and is responsible for the activities or work done.

In accordance with the factors in motivation, intrinsically, a person will be motivated from within to enjoy their work, allowing them to use creativity and innovation and not need to be watched closely. While extrinsically, it tends to look at what is given by the organization to them and its performance is directed to the acquisition of the things they want from the organization. Extrinsic factors will not encourage employees to work well so as not to produce optimal and effective performance.

Naylin (2000) that motivation can be improved if the desires and needs expected by employees can be fulfilled. These needs and desires include: 1) employees want to be praised and acknowledged, 2) employees need assurance of work, 3) employees need opportunities to advance and gain experience, 4) employees need communication, 5) employees need fair, justice, will be guaranteed main of the treatment of subordinates in matters, promotion, awards, provision of service facilities and so on.

One way that can be seen from the work of employees is the job satisfaction they experience. Puspitawati and Riana (2014), that job satisfaction can be viewed from two 
different sides, namely the employee side and the organizational side. On the employee side, work atmosphere will bring pleasant feelings to work while in terms of organization, job satisfaction will increase productivity, improve employee attitudes and behavior so as to produce performance optimization.

In general, job satisfaction is personal or individual that can be felt by employees both positive and negative feelings towards the work they complete. Job satisfaction is very closely related to the motivation given by the leadership to employees so that it can create a harmonious relationship between leaders and subordinates. Belo, et al (2014) positive job satisfaction means that the more employees feel satisfied with the job, then they will be more committed to the progress of the organization. Thus to improve employee performance, the organization needs to increase salaries and provide benefits that have not been or have not been in accordance with responsibilities, leaders who give praise for the results of the work that has been done, the application of regulations by the leadership and the opportunity to occupy different positions.

Each employee has a different level of satisfaction, in accordance with the system of values that apply to him. This is because there are differences in carrying out the work, the more aspects of the work desired by the employee, the higher the satisfaction he feels. Rivai (2004), explained that job satisfaction is an individual's feeling towards his work. This feeling is in the form of an assessment of how far the work as a whole is able to satisfy its needs.

Environmental conditions in the organization also greatly affect job satisfaction. The more comfortable working environment conditions, the higher the job satisfaction felt by employees so that the spirit of carrying out the work well will also be high. Job satisfaction is a feeling that can support the individual's self that relates to his work and his condition. Feelings related to work involve aspects such as wages and salaries received, career development opportunities, relationships with other employees, work placement, type of work, organizational structure, quality of supervision. While feelings related to him include age, health conditions, abilities and education.

Performance is closely related to the results of one's work in an organization, by carrying out an activity and perfecting it in accordance with its responsibilities with the expected results. Thus, performance is a series of actions in the execution of tasks that have been completed by someone in accordance with the predetermined and expected results. Performance is a combination of ability and effort to produce what is done, which aims to produce good work, then one must have the ability, will, effort and support from the environment. Willingness and effort to generate motivation, then after there is motivation someone will display behavior to work and create job satisfaction.

There are 4 (four) elements contained in performance, as stated by Tika (2006), namely the results of job functions, factors that influence employee performance, achievement of organizational goals and a certain time period. Yusniar (2016), also stated that there are 3 (three) main factors that influence performance, namely the individual (ability to work), work effort (desire to work), and organizational support (opportunity to work).

Measurements made on employee performance play an important role in increasing motivation, job satisfaction as well as developing ideas through innovative behavior in the completion of assigned tasks. Performance assessment is a key factor for developing an organization effectively and efficiently. The results of the assessment in performance can show the professionalism of individual employees and work teams in an effort to achieve organizational goals. The importance of performance in the organization, as stated by Pasolong (2013), namely: 
1. The achievement of organizational goals that cannot be separated from the resources owned by the organization that are driven or run by employees who play an active role as actors in the effort to achieve organizational goals.

2. To encourage the most effective and productive level of employee performance in the social interaction of the organization, there will always be expectations of subordinates to superiors or vice versa.

3. Efforts to achieve the objectives of the organization legally, do not violate the law and are in accordance with morals and ethics.

4. To find out the ability of employees to do something with certain expertise.

\section{Conclusion}

To deal with various changes that occur as a result of globalization, encourage each organization to make reforms, changes or improvements to strengthen its organization. In other words, every organization must have certain advantages, supported by a strong organizational culture and understood and accepted by all members of the organization consistently. The culture of an organization has a strong character and is related to organizational performance so that the leader will try to influence every member involved in carrying out activities by providing the best service to improve organizational performance. Thus, in realizing professional employee performance, it can be done by paying attention to organizational culture. So, Hisham, et.al (2018) that there is a significant relationship between employee motivation to do entrepreneurship and innovative behavior and that is both intrinsic and extrinsic motivation that influences innovative behavior.

Measuring the relationship of organizational culture in order to achieve good organizational performance, an intervening factor is needed such as work motivation, job satisfaction, and innovative behavior as a supporting factor in achieving the desired organizational performance. As explained earlier in the chapter of the theory that in improving employee performance, organizational culture is also thought to influence the three intervening variables, because:

1. Organizational culture guides individuals to behave and gives instructions to them about what must be followed and learned in achieving organizational goals that have been set. In organizations, essentially there is interaction between individuals according to their respective roles and functions in order to achieve common goals. Every organization has a different culture, so the organization is always unique and wants to look unique. Culture greatly influences work motivation in the organization, because of the provision of direction, support and compensation in settlement so as to increase employee morale.

2. Relevant organizational culture in creating a conducive and comfortable atmosphere so that employees can work well in the completion of the work assigned to them. Organizational culture is very influential on the level of job satisfaction that can improve employee morale. Positive job satisfaction is strongly influenced by a positive organizational culture.

3. Organizational culture is a daily manifestation of the values and traditions that underlie the organization which will be seen in how employees behave, employee expectations of the organization and vice versa. Organizational culture is very influential on the behavior of members of certain organizations. For an innovative leader, all the rules of the game that exist in the organization where he takes shelter will always be followed and become a guide when doing all activities. If the culture in the organization is strong, this will support the behavior of leaders in carrying out innovations that are supportive towards improving 
organizational performance. Thus, a good organizational culture will provide an opportunity for innovative leaders to act in accordance with organizational rules that are in the interests of the organization.

\section{References}

[1] Belo, et al (2014) Pengaruh Kepuasan Kerja dan Motivasi Kerja Terhadap Komitmen Organisasional dan Kinerja Karyawan di Kantor Palang Merah Timor Leste. E-Jurnal Ekonomi dan Bisnis Universitas Udayana Volume 3 No. 12 Tahun 2014 ISSN: 2337 3067; Universitas Udayana, Bali

[2] Handoko, Hani T. (2014). Manajemen Personalia dan Sumber Daya Manusia. Edisi 2. Yogyakarta: BPFE

[3] Hisham, Amar, et.al. (2018). Employees Motivation To Undertake Entrepreneurship and Innovative Behaviour: UNITEN KSHAS. Global Business and Management Research: An International Journal. Vol. 10, No.3 (2018, Special Issue)

[4] Kotter, John P, dan James L Heskett. (1998). Corporate Culture and Performance. Dampak Budaya Perusahaan Terhadap Kinerja, terjemahan Benyamin Molan. Jakarta: PT. Prenhallindo.

[5] Nankervis, AR., R.L., Compton, and T.E. McCarthy, (1993), Strategic Human Resource Management. South Melbourne, ITP Thomas Nelson Australia.

[6] Naylin, (2000), Pemenuhan Kebutuhan Pegawai Kunci Menuju Motivasi dalam A. DaleTimple, Motivasi Pegawai (Motivation of Personal), Buku III, Jakarta: Penerbit PT. Alex Media Komputindo.

[7] Prayudhayanti, Ndaru, Bondan. (2014), Peningkatan Perilaku Inovatif Melalui Budaya Organisasi, Jurnal Ekonomi dan Bisnis Volume 15 No. 2 Tahun 2014, ISSN 1411 2280 Universitas Islam Sultan Agung.

[8] Rivai, Veithzal, (2004) Manajemen Sumber DAya Manusia, Jakarta, Penerbit Raja Grafindo Persada.

[9] Robbins, S.P. (2008), Organizational Behavior. Concept, Controversies, Applications, Englewood Cliffs, NJ: Prentice Hall.

[10] Tika, Muhammad Poburudu, (2006). Budaya Organisasi dan Peningkatan KinerjaPerusahaan, Jakarta, PT. Bumi Aksara.

[11] Waridin dan Masrukhin, (2006), Pengaruh Motivasi Kerja, kepuasan kerja, Budaya Organisasi dan kepemimpinan terhadap Kinerja Pegawai, Ekonomi Bisnis, Volume 7, No. 2.

[12] Wallace, J., J. Hunt, \& C. Richards, (1999), The Relationship Between Organizational Culture, Organizational Climate and Managerial Values. The International Journal of Public Sector Management. 12 (7): 548-567.

[13] Yusniar (2016) Pengaruh Budaya Organisasi Terhadap Kinerja Melalui Motivasi di Sekretariat Daerah Kabupaten Aceh Utara. Journal of Economic Management and Business Volume 17 No. 1 Edisi April Tahun 2016 ISSN: 1412- 968X 